\title{
TANTANGAN PEMURIDAN ANAK DALAM ERA REVOLUSI INDUSTRI 4.0 DI SD INPRES 1 TIRTAKENCANA
}

\author{
Yahya Hardian Restu, Fransisko Oes Asa \\ Ernie Rahman, Desry Narliany Linggamo \\ Sekolah Tinggi Teologi Star's Lub Luwuk Banggai \\ Yahyahardian742@gmail.com
}

\begin{abstract}
This study discusses the challenges faced by Christian education teachers in carrying out discipleship tasks for Christian students in the era of the industrial revolution 4.0 at SD Inpres 1 Tirtakencana, Banggai district, Central Sulawesi. There were nine informants involved, consisting of two teachers of Christian religious education and seven parents of students. The method used is qualitative with interviews as a data collection technique. The study results show that PAK teachers have tried to use digital media in discipleship. Still, the Christian teacher discipleship efforts have not had much impact on students' character development, which can be seen from the differences in student behavior when at home, which shows poor behavior.
\end{abstract}

Keyword: discipleship, christian education teachers, industrial revolution 4.0

\begin{abstract}
Abstrak. Penelitian ini membahas tentang tantangan yang dihadapi guru pendidikan agama Kristen dalam melakukan tugas pemuridan kepada peserta didik yang beragama Kristen di era revolusi industri 4.0 di SD Inpres 1 Tirtakencana, kabupaten Banggai, Sulawesi Tengah. Informan yang dilibatkan berjumlah sembilan orang, yang terdiri atas dua orang guru pendidikan agama Kristen dan tujuh orang tua peserta didik. Metode yang digunakana adalah kualitatif dengan wawancara sebagagi teknik pengambilan data. Hasil penelitian menunjukkan: 1) guru PAK sudah berusaha menggunakan media digital dalam pemuridan, 2) upaya pemuridan guru PAK belum terlalu membawa dampak pada pengembangan karakter peserta didik yang tampak dari adanya perbedaan perilaku peserta didik ketika di rumah yang menunjukan perilaku kurang baik.
\end{abstract}

Kata kunci: pemuridan, guru PAK, revolusi industri 4.0

\section{PENDAHULUAN}

Dengan berbagai inovasi di era revolusi industri 4.0, manusia harus dapat beradaptasi dengan berbagai perkembangan teknologi yang semakin maju seiring dengan perkembangan zaman. Untuk itu setiap orang percaya perlu menyesuaikan diri terhadap setiap perkembangan. Dalam bidang pendidikan, hal itu dapat 
BONAFIDE: Jurnal Teologi dan Pendidikan Kristen

www.jurnal.sttissiau.ac.id/Volume 2/Nomor 2/Desember 2021/hal.237-252

dilakukan dengan cara memanfaatkan teknologi dalam proses pembelajaran melalui audio-visual. Khusus untuk Pendidikan Agama Kristen, menurut Camerling dkk, dengan memanfaatkan teknologi media digital, guru PAK juga dapat melakukan misinya dalam memuridkan peserta didik. Media digital merupakan menjadi salah satu ladang pelayanan yang efektif di era revolusi industri 4.0" (Camerling, Lauled, and Eunike 2020).

Pemuridan sangat penting dalam pembentukan karakter peserta didik agar memiliki karakter yang baik sesuai dengan ajaran Kristen. Aprianto dan Santosa (2020) berpendapat bahwa proses pemuridan dan penginjilan dapat meningkatkan perkembangan karakter jujur pada anak. Demikian juga dengan pendapat Mangalik bahwa pembentukan karakter anak yang mencerminkan karakteristik kepemimpinan Kristen atau memimpin dengan menyerupai Kristus dapat dilakukan dengan jalan pemuridan kepada anak (Mangalik 2020). Oleh karena itu pemuridan perlu diterapkan oleh guru PAK kepada peserta didik sebagai strategi dalam menghadapi revolusi industri 4.0.

Hal ini didukung oleh pendapat Donnalo (2020) yang mengatakan bahwa melakukan proses pemuridan di era revolusi industri 4.0 sangat menunjang untuk menghadapi perubahan zaman dan berbagai aspek yang ada didalamnya, terutama kemajuan teknologi yang serba canggih sehingga perlu tuntunan, bimbingan dan arahan untuk menjadikan seseorang serupa dengan Kristus. Untuk itu dalam menghadapi era revolusi industri 4.0 diperlukan pemuridan untuk mempersiapkan generasi yang siap menghadapi berbagai tantangan dan berbagai pengaruhnya agar generasi muda Kristen dapat mencerminkan karakter Kristus di tengah Yahya Hardian Restu, Fransisko Ues Asa, Ernie Rahman, Desry Narlıany Linggamo '238 
BONAFIDE: Jurnal Teologi dan Pendidikan Kristen

www.jurnal.sttissiau.ac.id/Volume 2/Nomor 2/Desember 2021/hal.237-252

perkembangan zaman. Febriani (2020) juga berpendapat bahwa proses pemuridan merupakan solusi yang efektif untuk menghadapi tantangan dan sebagai panggilan pelayanan di era industri 4.0 untuk membentuk generasi yang beridentitas Kristen dan bertumbuh didalam iman.

Pemuridan adalah suatu proses membuat seseorang dapat bertumbuh dan memiliki karakter Kristus (Nainupu, Tabrani, and Frets 2020). Karena itu pemuridan merupakan sebuah Pendidikan Agama Kristen. Pemuridan adalah suatu usaha yang dilakukan oleh seorang guru secara sistematis dengan tujuan agar anak dapat meneladani Kristus dalam kehidupan sehari-hari. Selain itu pemuridan juga dapat dikatakan sebagai pendidikan yang berdasarkan nilai-nilai Kristen yang terdapat dalam Alkitab.

Di dalam pemuridan peran guru sangat besar. Ina menegaskan bahwa pemuridan tidak bisa dilihat hanya sebuah tugas dari lembaga pendidikan, tetapi harus merupakan keinginan yang lahir dari dalam diri pendidik itu sendiri. Apalagi di tengah era disrupsi saat ini (dalam Tenny and Arifianto 2021). Apabila pemuridan diidentikkan dengan Pendidikan Agama Kristen (PAK), maka keberhasilan pemuridan di sekolah sangat ditentukan oleh peran guru PAK. Seperti dikatakan Telaumbanua bahwa guru PAK selain berperan sebagai pengajar, juga bertanggung jawab untuk memperlengkapi dan membimbing peserta didiknya yang beragama Kristen untuk bertumbuh di dalam Yesus Kristus (Telaumbanua 2018).

Di tengah era revolusi industri 4.0, guru perlu memanfaatkan perkembangan teknologi, khususnya teknologi informasi untuk menjalankan Yahya Hardian Restu, Fransisko Oes Asa, Ernie Rahman, Desry Narliany Linggamo 239 
BONAFIDE: Jurnal Teologi dan Pendidikan Kristen

www.jurnal.sttissiau.ac.id/Volume 2/Nomor 2/Desember 2021/hal.237-252

proses pemuridan atau penyelengaraan PAK. Seperti dikatakan Camerling et al (2020) bahwa dengan memanfaatkan media digital maka penyampaian firman Tuhan melalui pelajaran PAK dapat menjadi metode yang kreatif dan inovatif melalui media audio-visual sehingga dapat menarik perhatian peserta didik yang lebih tertarik pada gambar, animasi bergerak dan video.

Pertanyaannya kemudian, sejauhmana guru PAK di sekolah menyadari hal tersebut? Sejauhmana guru PAK memanfaatkan teknologi informasi dalam pemuridan di sekolah di tengah era revolusi industri sekarang ini? Untuk menjawab pertanyaan-pertanyaan di atas, penulis melakukan penelitian di Sekolah Dasar Inpres 1 Tirtakencana, kecamatan Toili, kabupaten Banggai, propinsi Sulawesi Tengah. Pertimbangan memilih sekolah ini adalah adanya pelajaran Pendidikan Agama Kristen pada setiap kelas dan terdapat guru yang secara khusus mengajar mata pelajaran PAK.

Para siswa di sekolah ini juga sebagian besar telah memiliki smartphone. Namun Damayanti dkk menyampaikan bahwa memiliki smartphone dan mahir menggunakannya di usia dini sangat rentan membawa dampak buruk kepada mereka. Dampak tersebut antara lain membuat mereka malas untuk belajar, mudah marah dan suka membangkang kepada orang tua (Damayanti, Ahmad, and Bara 2020). Sebab itu, penulis melakukan penelitian di SD Inpres 1 Tirtakencana untuk mengetahui karakter peserta didik yang beragama Kristen dan bagaimana guru Pendidikan Agama Kristen melakukan pembimbingan terhadap peserta didik Kristen melalui pemuridan.

$\overline{\text { Yahya Hardian Restu, Fransisko Oes Asa, Ernie Rahman, Desry Narliany Linggamo } 240}$ 
BONAFIDE: Jurnal Teologi dan Pendidikan Kristen

www.jurnal.sttissiau.ac.id/Volume 2/Nomor 2/Desember 2021/hal.237-252

Penelitian serupa pernah dilakukan oleh Molawan dan Mosooli tentang Penggunaan Gadget dalam PAK untuk Memperdalam Kerohanian Peserta Didik pada tahun 2020. Penelitian tersebut mengkaji bagaimana sejauhmana gadget telah dimanfaatkan secara positif oleh para peserta didik untuk mengembangkan kerohanian mereka (Molawan and Mosooli 2020). Penelitian yang penulis lakukan ini lebih mengarah pada tantangan yang dihadapi oleh para guru PAK dalam melakukan pemuridan kepada peserta didik dengan menggunakan media digital sebagai bagian dari fenomena masyarakat dalam revolusi industri 4.0.

\section{METODE PENELITIAN}

Penelitian ini menggunakan metode kualitatif. Metode kualitatif juga disebut sebagai metode naturalistik karena penelitian dilakukan berdasarkan kondisi yang alamiah (Sugiyono 2016). Penggunaan metode kualitatif dalam penelitian ini diharapkan dapat memperoleh keterangan secara mendalam berkaitan dengan hal-hal yang menjadi pokok pembahasan serta dapat menemukan jawabannya melalui penelitian ini dan memperoleh deskripsi yang jelas terkait data dan informasi yang dibutuhkan agar sesuai dengan fakta tanpa rekaan semata.

Penulis menggunakan pendekatan studi kasus dalam penelitian ini sebagai bagian dari metode kualitatif. Studi kasus menurut Merriam dan Tisdell (2015) adalah deskripsi dan analisis secara mendalam dari bounded system, yakni sebuah sistem yang tidak dapat dilepaskan dari kasus yang satu dengan kasus lainnya (dalam Hidayat 2019).

Yahya Hardian Restu, Fransisko Oes Asa, Ernie Rahman, Desry Narliany Linggamo 241 
Dalam penelitian ini, pengumpulan data dilakukan dengan teknik wawancara. Teknik ini tepat dipilih apabila peneliti ingin menggali secara mendalam pemahaman informan mengenai suatu hal (Sugiyono 2016). Penulis akan mewawancarai informan yang terdiri dari guru Pendidikan Agama Krisetn sebanyak dua orang dan orang tua siswa yang beragama Kristen sebanyak tujuh orang. Guru dan orang tua di anggap sebagai orang yang mengamati perilaku peserta didik ketika di rumah, dan guru terkait dengan keberhasilan strategi pemuridan guru Pendidikan Agama Kristen terhadap peserta didik yang ada di sekolah.

Teknik analisis data dalam penelitian ini menggunakan model yang dikemukakan oleh Miles dan Huberman (1984) yaitu "data reduction, data display, conclusion drawing/ verification” (Sugiyono 2016). Analisis data dalam penelitian ini dilakukan dengan langkah-langkah sebagai berikut : 1) mengumpulkan data dengan mencatat semua temuan di lapangan melalui pengamatan, wawancara dan dokumentasi. 2) memilih data yang dianggap pokok dan penting dari hasil pengamatan, wawancara dan dokumentasi untuk memberikan gambaran yang lebih jelas. 3) mendeskripsikan data yang telah diklasifikasi. 4) membuat kesimpulan dalam bentuk laporan hasil penelitian.

\section{HASIL PENELITIAN}

Dari penelitian yang telah dilakukan, hasil yang diperoleh bahwa kedua guru lebih cenderung melakukan pendekatan secara persuasif dalam hal penekanan pada motivasi belajar kepada para anak didiknya dengan tujuan 
BONAFIDE: Jurnal Teologi dan Pendidikan Kristen

www.jurnal.sttissiau.ac.id/Volume 2/Nomor 2/Desember 2021/hal.237-252

memberikan perubahan perilaku kepada peserta didik yang malas sehingga mereka memiliki keberanian untuk meminta tolong kepada guru, bertanya mengenai materi pelajaran yang belum dipahami, dan memimpin doa di dalam kelas serta perubahan perilaku seperti yang sebelumnya malas untuk mengikuti dan malas untuk belajar secara perlahan mulai berubah. Namun berdasarkan keterangan yang diberikan orang tua peserta didik bahwa dalam aktifitas seharihari di rumah, masih terdapat perilaku kurang baik, seperti membantah orang tua, kurang sabar, tidak mendengarkan perkataan orang tua, manja dan malas belajar. Hal ini menunjukan bahwa ada perbedaan perilaku peserta didik ketika berada di sekolah dan di rumah.

Dalam pemanfaatan media digital, guru Pendidikan Agama Kristen mencari berbagai informasi materi pembelajaran dari berbagai media seperti internet dan media sosial lainya seperti Whatsapp, Telegram, Youtube, Facebook dll. Informasi yang didapatkan berguna untuk mendukung proses pembelajaran PAK maupun upaya pemuridan kepada anak didik. Selain itu, melalui hasil wawancara Guru A mengatakan bahwa "Sebagai dampak dari pandemi Virus Corona dimana diberlakukannya belajar online, kami sebagai guru PAK menggunakan aplikasi obrolan online untuk membagikan tugas kepada para murid". Guru B menambahkan pula "Menurut laporan para orang tua, anak-anak menjadi lebih semangat menyimak materi saat belajar ketika materi yang dikirimkan dalam bentuk video animasi seperti tokoh-tokoh Alkitab dan ayat hafalan Alkitab".

$\overline{\text { Yahya Hardian Restu, Fransisko Oes Asa, Ernie Rahman, Desry Narliany Linggamo } 243}$ 
BONAFIDE: Jurnal Teologi dan Pendidikan Kristen

www.jurnal.sttissiau.ac.id/Volume 2/Nomor 2/Desember 2021/hal.237-252

Dalam penelitian ini, peneliti juga melakukan wawancara kepada orang tua peserta didik sebanyak tujuh orang untuk mengetahui karakter peserta didik ketika berada di rumah untuk mengetahui tingkat keberhasilan guru Pendidikan Agama Kristen dalam pemuridan peserta didik dalam memanfaatkan media digital di era evolusi industry 4.0 dan didapatkan hasil sebagai berikut:

Enam orang informan mengatakan bahwa perilaku anak ketika di rumah masih menunjukan perilaku tidak baik seperti membantah orang tua, banyak bermain, malas belajar, tidak sabar, manja dan lambat melakukan sesuatu yang diperintahkan orang tua. Tujuh Informan mengatakan bahwa anak lebih banyak menggunakan Handphone untuk bermain game dan membuka media sosial seperti Youtube dan Tiktok di luar jam mengerjakan tugas dan belajar.

Hal ini menunjukkan bahwa pemuridan sebagai bentuk pembentukan karakter dengan menggunakan media teknologi informasi belum membawa dampak positif dalam kehidupan sehari-hari peserta didik.

\section{PEMBAHASAN}

Apakah pemuridan di SD Inpres 1 Tirtakencana dengan memanfaatkan media digital telah berkontribusi bagi pembentukan karakter anak didik? Pertanyaan demikian tampaknya tidak terjawab melalui penelitian ini. Di satu sisi guru PAK sudah berusaha menggunakan media digital dalam pembelajaran, tetapi di sisi lain karakter peserta didik masih tampaknya belum banyak terbentuk ke arah yang lebih positif. Bahkan peserta didik cenderung menggunakan gadget 
BONAFIDE: Jurnal Teologi dan Pendidikan Kristen

www.jurnal.sttissiau.ac.id/Volume 2/Nomor 2/Desember 2021/hal.237-252

untuk kegiatan yang kurang mendukung pengembangan karakter positif. Hal ini tampaknya bisa dijelaskan sebagai berikut.

\section{Pandemi Covid-19 dan "Pemaksaan” Guru Menggunakan Media Digital}

Kehadiran pandemi covid-19 telah membawa perubahan besar di dunia pendidikan. Akibat pembatasan sosial, sekolah dipaksa menjalankan pembelajaran daring. Guru-guru pun dituntut melakukan berbagai inovasi agar mampu melaksanakan pembelajaran daring. Mereka juga perlu memiliki wawasan dan ketrampilan memadai terkait dengan media pembelajaran daring (Adib 2021).

Artinya keterlibatan guru secara lebih intens dalam penggunaan teknologi informasi baru mengalami peningkatan sejak masa pandemi covid-19. Bagi sebagian besar guru, penggunaan teknologi informasi dalam pembelajaran merupakan hal baru. Hal ini terjadi juga di SD Inpres 1 Tirtakencana. Pemanfaatan teknologi seperti smartphone dan media sosial berbasis internet kurang dgiatkan sebagai media alternatif dalam pemuridan peserta didik karena sebelum masa pandemi Covid-19 guru PAK tidak memanfaatkan gadget untuk memberikan bimbingan dan pengarahan kepada peserta didik di luar jam sekolah maupun kegiatan sekolah.

\section{Penguasaan Guru PAK terhadap Media Digital}

Dengan berbagai inovasi di era revolusi industri 4.0, manusia harus dapat beradaptasi dengan berbagai perkembangan teknologi yang semakin maju seiring dengan perkembangan zaman. Demikian juga dengan guru PAK, di tengah perkembangan teknologi yang semakin canggih, guru PAK dapat menggunakan 
BONAFIDE: Jurnal Teologi dan Pendidikan Kristen

www.jurnal.sttissiau.ac.id/Volume 2/Nomor 2/Desember 2021/hal.237-252

gadget untuk melakukan pemuridan dengan memanfaatkan media digital. Camerling dkk mengatakan bahwa dengan memanfaatkan teknologi, guru PAK juga dapat melakukan misinya dalam memuridkan peserta didik dengan memanfaatkan media digital karena dapat menjadi salah satu ladang pelayanan yang efektif di era revolusi industri 4.0 (Camerling, Lauled, and Eunike 2020). Oleh karena itu penggunaan media digital dalam upaya pemuridan peserta didik perlu dimaksimalkan dan menjadi salah satu media yang tepat untuk digunakan di era saat ini.

Pemanfaatan teknologi seperti gadget dan internet pada era saat ini dapat menjadi strategi yang efektif bagi guru PAK karena teknologi ini memungkinkan pendidik untuk terus dapat berkomunikasi dengan peserta didiknya untuk memberikan bimbingan serta arahan secara efektif. Media yang dapat digunakan oleh pendidik untuk menjalin komunikasi dengan peserta didik yaitu dengan menggunakan gadget, salah satunya dengan menggunakan media sosial.

Media sosial merupakan media yang sangat lumrah digunakan untuk berkomunikasi dan hampir semua orang menggunakannya saat ini, begitu juga di kalangan peserta didik. Untuk itu media sosial dapat dimanfaatkan sebagai media bagi para guru PAK untuk memberikan bimbingan dan pengarahan kepada peserta didik di era revolusi industri 4.0. Tujuannya agar tetap terjalin komunikasi tanpa dibatasi oleh ruang dan waktu.

Pada Pendidikan Jarak Jauh di SD Inpres 1 Tirtakencana, guru PAK memanfaatkan media sosial pada proses pembelajaran Pendidikan Agama Kristen melalui aplikasi Whatsapp dengan cara mengirimkan screenshot materi kepada Yahya Hardian Restu, Fransisko Oes Asa, Ernie Rahman, Desry Narliany Linggamo 246 
BONAFIDE: Jurnal Teologi dan Pendidikan Kristen

www.jurnal.sttissiau.ac.id/Volume 2/Nomor 2/Desember 2021/hal.237-252

peserta didik atau mengirimkan video yang di unduh dari Youtube dan dikirimkan melalui grup Whatsapp kelas. Begitu juga pada pemberian tugas, guru PAK mengirimkan Screenshoot tugas yang akan dikerjakan dan anak didik dapat mengerjakan tugas melalui buku pelajaran pendidikan agama Kristen yang mereka miliki kemudian mengirim tugasnya melalui aplikasi Whatsapp secara pribadi dalam bentuk foto.

Guru PAK mengunduh video-video animasi di Youtube tentang kisahkisah di Alkitab serta memberikan penjelasan mengenai kisah tersebut dan memanfaatkan media sosial seperti Facebook, Whatsapp, Masangger, dll untuk kemudian para orang tua membagikan kepada anaknya sebagai materi pelajaran. Dari kegiatan tersebut diketahui bahwa guru PAK memiliki kesiapan dan melek dalam teknologi khususnya dalam proses pemuridan pada usia dini.

Guru PAK menggunakan aplikasi Whatsapp sebagai media untuk mengirimkan materi pelajaran, memberikan tugas, dan untuk mengumpulkan tugas. Sementara itu ia menggunakan Youtube untuk mencari bahan pembelajaran berupa video pembelajaran yang berhubungan dengan materi yang diajarkan. Sehingga proses pembelajaran murid akan lebih menyenangkan dalam bentuk video dari materi yang diberikan.

Namun demikian, para guru tetap menghadapi sejumlah hambatan. Terkait dengan pembelajaran daring Rasidi dkk menemukan adanya berbagai hambatan yang dihadapi guru, antara lain: (1) implementasi perangkat pembelajaran yang disusun belum dapat diimplementasikan secara optimal, termasuk pemanfaatan e- 
BONAFIDE: Jurnal Teologi dan Pendidikan Kristen

www.jurnal.sttissiau.ac.id/Volume 2/Nomor 2/Desember 2021/hal.237-252

learning dalam pembelajaran. (2) Keterbatasan kuota internet dan handphone android peserta didik (Rasidi, Hikmatullah, and Sobry 2021).

Selain itu Winda dan Dafit menemukan juga dalam penelitian mereka bahwa para guru mengalami kesulitan terkait dengan kemampuan merancang dan mengoperasikan media berbasis IT dan media berbasis IT. Ditambah lagi dengan sarana dan prasarana yang tidak lengkap di sekolah (Winda and Dafit 2021).

Para guru PAK di SD Inpres 1 Tirtakencana juga menghadapi hal serupa baik dalam pembelajaran daring maupun luring dengan penggunaan media informasi. Mereka masih perlu belajar banyak berkaitan media informasi serta perlu dukungan sarana di sekolah.

\section{Pemuridan Tetap Membutuhkan Kontak Langsung}

Srigati mengemukakan bahwa pembentukan karakter peserta didik tetap bisa dilakukan meskipun menggunakan media komunikasi, termasuk dalam pembelajaran daring. Nilai-nilai seperti disiplin, jujur, dan bertanggung jawab tetap bisa diajarkan melalui proses belajar daring (Srigati 2021). Yasir dan Indra menunjukkan bahwa pembentukan karakter melalui pembelajaran daring bisa dilakukan dengan metode metode motivasi saat pembelajaran dan pemberian contoh sikap (Yasir and Indra 2021).

Namun demikian Shiddiq dkk menemukan bahwa pembelajaran tatap muka berpengaruh terhadap kemampuan afektif warga belajar Pendidikan Kesetaraan Paket C di PKBM Suaka Anak Negeri Jember. Hal ini terjadi karena 
BONAFIDE: Jurnal Teologi dan Pendidikan Kristen

www.jurnal.sttissiau.ac.id/Volume 2/Nomor 2/Desember 2021/hal.237-252

peserta belajar dapat melibatkan diri dalam keseluruhan proses, baik mental maupun fisik (Shiddiq, Marijono, and Imsiyah 2018).

Pemuridan adalah proses pembentukan karakter agar lebih serupa dengan karakter Kristus. Sebab itu, meskipun di tengah derasnya serbuan teknologi digital tetapi guru PAK tetap perlu melakukan pelayanan pastoral/kunjungan kepada peserta didik untuk lebih memahami kesulitan atau persoalan yang anak didik alami khususnya. Termasuk di dalamnya memahami materi pelajaran yang diberikan dan bagi anak didik yang perlu dibimbing karena malas mengerjakan tugas demi perubahan perilaku yang lebih baik. Hal ini dilakukan sebagai wujud upaya tanggung jawab sebagai seorang guru PAK untuk memberi dukungan, semangat, dan memantau perkembangan anak didik.

\section{Pemuridan Membutuhkan Kerjasama dengan Orang Tua}

Bagaimanapun juga waktu yang dihabiskan anak setiap hari lebih banyak di rumah dibandingkan di sekolah. Sebab itu, keberhasilan pembentukan karakter anak sangat dipengaruhi oleh pendidikan yang berlangsung di rumah. Prasanti dan Fitriani mendeskripsikan bahwa bahwa proses pembentukan karakter anak diawali dari keluarga, kemudian dilanjutkan dengan sekolah, dan komunitas yang diikuti anak tersebut. Tetapi faktor utama yang menentukan adalah keluarga sebagai komunitas terkecil dan pertama bagi para anak (Prasanti and Fitriani 2018).

Dalam penelitian ini pada SD Inpres 1 Tirtakencana tampak bahwa perubahan karakter anak didik dalam penggunaan media digital dalam misi pemuridan belum menunjukkan perubahan. Hal ini karena sikap anak didik yang 
BONAFIDE: Jurnal Teologi dan Pendidikan Kristen

www.jurnal.sttissiau.ac.id/Volume 2/Nomor 2/Desember 2021/hal.237-252

ditunjukkan di sekolah dan di rumah mengalami perbedaan. Sebab itu, partisipasi orang tua sangatlah dibutuhkan untuk mengembangkan karakter anak.

\section{KESIMPULAN}

Berdasarkan hasil penelitian dan pembahasan, dapat diambil kesimpulan bahwa sebagai upaya dalam pemuridan anak didik yang beragama Kristen di SD Inpres 1 Tirtakencana, guru PAK melakukan beberapa cara sebagai strategi pemuridan kepada peserta didik. Upaya yang dilakukan adalah dengan membangun relasi dengan peserta didik, membuat atau mengadakan kegiatan rohani sekolah, mengitegrasikan firman Tuhan dalam pembelajaran dan memanfaatkan media digital untuk mendukung keberlangsungan pembelajaran Penidikan Agama Kristen dengan memanfaatkan aplikasi Whatsapp dan Youtube di masa pandemi Covid-19.

Penggunaan gadget sebagai media untuk melakukan pemuridan kepada peserta didik kurang maksimal karena pemanfaatan gadget dalam pembelajaran Pendidikan Agama Kristen hanya dilakukan setelah masa pandemi Covid-19. Begitu juga strategi yang digunakan guru PAK di SD Inpres 1 Tirtakencana belum sepenuhnya dapat memberikan pengaruh terhadap perilaku atau karakter anak didik ketika berada di rumah. Hal tersebut tampaknya disebabkan kurangnya pemahaman dan penguasaan guru PAK terhadap media IT, karena pembelajaran seperti ini masih baru. Selain itu faktor terbatasnya sarana yang tersedia di sekolah turut berpengaruh. 
BONAFIDE: Jurnal Teologi dan Pendidikan Kristen

www.jurnal.sttissiau.ac.id/Volume 2/Nomor 2/Desember 2021/hal.237-252

Meskipun pemuridan di era revolusi industri 4.0 ini penting untuk menggunakan media digital, namun karena pemuridan lebih memberikan penekanan pada pembentukan karakter maka kontak langsung antara guru dan peserta didik tetap diperlukan. Peran orang tua juga sangat penting mengingat anak lebih banyak menghabiskan di tengah keluarga setiap hari.

\section{DAFTAR PUSTAKA}

Adib, Hamdan. 2021. "Problematika Penggunaan Gadget Dalam Pembelajaran Masa Pandemi Covid-19 (Dampak Dan Solusi Bagi Kesehatan Siswa)." Asatiza: Jurnal Pendidikan 2 (3): 170-79. https://doi.org/10.46963/ASATIZA.V2I3.391.

Camerling, Yosua Feliciano, Mershy Ch. Lauled, and Sarah Citra Eunike. 2020. "Gereja Bermisi Melalui Media Digital Di Era Revolusi Industri 4.0." Visio Dei: Jurnal Teologi Kristen 2 (1): 1-22. https://doi.org/10.35909/visiodei.v2i1.68.

Damayanti, Eka, Arifuddin Ahmad, and Ardias Bara. 2020. "Dampak Negatif Penggunaan Gadget Berdasarkan Aspek Perkembangan Anak Di Sorowako." Martabat: Jurnal Perempuan Dan Anak 4 (1): 1-22. https://doi.org/10.21274/MARTABAT.2020.4.1.1-22.

Donnalo, Reni Sandy. 2020. Implementasi Pemuridan Kontekstual Untuk Meningkatkan Pelayanan Pemuda Di Era Revolusi Industri 4.0 Di Gereja Toraja Jemaat Mebali. Makale: Sekolah Tinggi Agama Kristen Negeri Toraja.

Febriani, Febriani. 2020. "Implementasi Model Pemuridan Kontekstual Sebagai Panggilan Pelayanan Terhadap Generasi Milenial Di Era Industri 4.0." https://doi.org/10.31219/osf.io/4u3ba.

Hidayat, Taufik. 2019. "Pembahasan Studi Kasus Sebagai Metodologi Penelitian." Universitas Muhammadiyah Purwokerto 3 (August): 1.

Mangalik, Lisdayanti Anita. 2020. "Model Pemuridan Kontekstual Untuk Membentuk Karakter Kepemimpinan Kristen Bagi Anak Remaja." https://doi.org/10.31219/OSF.IO/GRMQZ.

Molawan, Yani Margaretha, and Ermin Alperiana Mosooli. 2020. "Penggunaan Gadget Dalam PAK Untuk Memperdalam Kerohanian Peserta Didik." BONAFIDE: Jurnal Teologi Dan Pendidikan Kristen 1 (1): 104-22. https://doi.org/10.46558/bonafide.v1i1.13.

Nainupu, Melben, Ahmad Tabrani, and Keriapy Frets. 2020. "Pemuridan Sebagai Yahya Hardian Restu, Fransisko Oes Asa, Ernie Rahman, Desry Narliany Linggamo 251 
BONAFIDE: Jurnal Teologi dan Pendidikan Kristen

www.jurnal.sttissiau.ac.id/Volume 2/Nomor 2/Desember 2021/hal.237-252

Upaya Menanamkan Iman Kepada Kristus Pada Mahasiswa Stak Terpadu Pesat Salatiga." Vox Dei: Jurnal Teologi Dan Pastoral 1 (2): 104-17. https://doi.org/10.46408/VXD.V1I2.34.

Prasanti, Ditha, and Dinda Rakhma Fitriani. 2018. "Pembentukan Karakter Anak Usia Dini: Keluarga, Sekolah, Dan Komunitas? (Studi Kualitatif Tentang Pembentukan Karakter Anak Usia Dini Melalui Keluarga, Sekolah, Dan Komunitas)." Jurnal Obsesi : Jurnal Pendidikan Anak Usia Dini 2 (1): 1319. https://doi.org/10.31004/OBSESI.V2I1.2.

Rasidi, Muhamad Ahyar, Nurrismi Hikmatullah, and M. Sobry. 2021. "Hambatan Guru Dalam Pembelajaran Daring: Studi Kasus Di Kelas V MIN 2 Kota Mataram." Jurnal Ilmiah Pendidikan Dasar 8 (2): 159-74. https://doi.org/10.30659/PENDAS.8.2.159-174.

Santosa, Santosa, and Guntur Firman Aprianto. 2020. "Implementasi Penginjilan Dan Pemuridan Dalam Pengembangan Karakter Jujur Anak Usia 9-10 Tahun." JURNAL TEOLOGI GRACIA DEO 2 (2): 94-108. https://doi.org/10.46929/GRACIADEO.V2I2.43.

Shiddiq, M. Zainul, Marijono Marijono, and Niswatul Imsiyah. 2018. "Pengaruh Pembelajaran Tatap Muka Terhadap Kemampuan Afektif Warga Belajar Pendidikan Kesetaraan Paket C Di Pkbm Suaka Anak Negeri Jember." Learning Community: Jurnal Pendidikan Luar Sekolah 2 (1): 14-16. https://doi.org/10.19184/JLC.V2I1.8092.

Srigati, Dewi. 2021. "Membentuk Karakter Siswa Di Masa Pandemi Covid-19." https://doi.org/10.31219/OSF.IO/VXC3Q.

Sugiyono. 2016. Metode Penelitian Kuantitatif, Kualitatif, Dan R\&D. Bandung: Alfabeta, CV.

Telaumbanua, Arozatulo. 2018. "Peranan Guru Pendidikan Agama Kristen Dalam Membentuk Karakter Siswa." Jurnal Fidei 1 (2): 219-31.

Tenny, Tenny, and Yonatan Alex Arifianto. 2021. "Aktualisasi Misi Dan Pemuridan Guru Pendidikan Agama Kristen Dalam Era Disrupsi.” Didaché: Journal of Christian Education 2 (1): 41-57. https://doi.org/10.46445/djce.v2i1.365.

Winda, Rose, and Febrina Dafit. 2021. "Analisis Kesulitan Guru Dalam Penggunaan Media Pembelajaran Online Di Sekolah Dasar." Jurnal $\begin{array}{lllll}\text { Pedagogi Dan Pembelajaran } 4 & 4 & \text { (2): } & 221 .\end{array}$ https://doi.org/10.23887/JP2.V4I2.38941.

Yasir, Muhammad Ibnu, and Syukri Indra. 2021. "Pembentukan Karakter Siswa Selama Melakukan Pembelajaran Jarak Jauh Di Kelurahan Pamoyanan." Educivilia: Jurnal Pengabdian Pada Masyarakat 2 (1): 105-15. https://doi.org/10.30997/EJPM.V2I1.3615.

Yahya Hardian Restu, Fransisko Oes Asa, Ernie Rahman, Desry Narliany Linggamo 252 